\title{
CONCLUSIVENESS OF TRUST TERMS IN TAX LITIGATION: CIRCUMVENTION OF THE CLIFFORD RULE*
}

TRUSTS are frequently used to minimize income taxes. Since each autonomous trust is taxed as a separate entity under the Internal Revenue Code, ${ }^{1}$ taxpayers can finesse the upper tax brackets by distributing income-producing property among several trusts. ${ }^{2}$ But though an independent trustee limited by the terms of a trust agreement ostensibly controls the distribution of trust income, the settlor or beneficiary often exercises far more personal influence than the trust instrument indicates. ${ }^{3}$ As a result, he may enjoy income without its tax burdens. ${ }^{4}$

*Funk v. Commissioner, 185 F.2d 127 (3d Cir. 1950).

1. INT. REv. CoDE $\$ 161$ (a) provides that the tax applied to the income of individuals shall be applicable in the same manner to the income of estates or property held in trust. "The tax shall be computed upon the net income of the estate or trust, and shall be paid by the fiduciary...." Id. $\S 161$ (b). The net income is computed "in the same manner and on the same basis as in the case of an individual. ..." Id. $\$ 162$.

Income which is payable to the beneficiary during the trust's taxable year, under the trust provisions, is deductible by the fiduciary, and must be reported by the beneficiary as his income. $I d . \$ 162(\mathrm{~b})$. But where distribution is left in the trustee's discretionary judgment under a standard set forth in the trust instrument, the trustee may deduct, and the beneficiary is taxed for, only such income as is "properly paid or credited during such year" to the beneficiary, under the trust standard. Id. \$162(c) (emphasis added).

2. Trusts are probably the most popular of income-splitting devices, although family partnerships and assignments of income are also frequently used techniques. 6 MerTENS, LaW of Federal Income Taxation $\$ 37.01$ (1949) (hereinafter cited as Mertens). A single individual may be the nominal beneficiary of many trusts. Thus there is technically no limit to the number of ways in which income can be split up.

The tax advantages of such income-splitting result because each portion of the total falls in a lower surtax bracket. The following example illustrates the saving: If a taxpayer reports a surtax net income of $\$ 200,000$ for calendar year 1951, he will pay a total surtax of $\$ 151,296$. But if taxable ownership of this income were split up, with equal shares to taxpayer and each of seven trusts, each recipient would pay only a tax of $\$ 9,586$ on $\$ 25,000$ income, a total tax of $\$ 76,688$. Revenue Act of 1951, Pub. L. No. 183, 82d Cong., 1st Sess. $\$ 101$ (a) (Oct. 20, 1951).

For a summary of cases and commentary on trust and other income-splitting techniques employed during the past two decades see Maginl, The IMPACT of Federal Taxes, c. II (1943); Surrey, Family Income and Federal Taxation, 24 TAXEs 980 (1946); and cases and articles cited in Note, 59 Y ALE L.J. 1529 n.1 (1950).

3. This occurs most frequently when all parties to the trust are members of the same family. See generally Surrey, supra, note 2 .

Explicit incorporation of unrestricted discretionary authority in the written instrument results in taxability of the holder, e.g., Richardson v. Commissioner, 121 F.2d 1 (2d Cir. 1941) (trustee has absolute power to revoke and vest corpus in himself); Altmaier v. Commissioner, 116 F.2d 162 (6th Cir. 1940), cert. denied, 312 U.S. 706 (1941) (settlor retains right to terminate the trusts jointly with wife). But grantor or beneficiary may exercise equally effective control even where there is no explicit articulation of their power in the terms of trust. E.g., Plimpton v. Commissioner, 135 F.2d 482 (1st Cir. 1943) (trust income not taxable to beneficiary where distributable in trustee's discretion, although beneficiary is one of trustees and the original donor of 
Eleven years ago, the Supreme Court sought to prevent such tax avoidance by determining taxable ownership of trust income on the basis of economic control. The Clifford case ${ }^{5}$ held a settlor-trustee taxable because his actual powers were equivalent to substantial ownership. ${ }^{6}$ The Court made clear that taxability was not to be based on the terms of the trust instrument alone. It required that these terms be scrutinized in the light of the relation of the parties and the way in which the trust was administered. ${ }^{\top}$

corpus to settlor, and the other trustee is amenable to his influence). For while the trustee is theoretically liable to prosecution in the state courts if he fails to follow the letter of the trust agreement, e.g., Conlin v. Murdock, 137 N.J. Eq. 12, 43 A.2d 218 (1945), ordinarily no one will bring a suit where all parties are members of the same family or good friends. See Cox v. Commissioner, 110 F.2d 934, 936 (10th Cir.), cert. denied, 311 U.S. 667 (1940).

4. Congress has attempted to tax income to settlors and beneficiaries where certain controls have been retained. INT. REv. CODE $\$ \S 161-167$. But these provisions have been too inflexible to offer much of an obstacle to "gimmick-minded" taxpayers. See MAGiLl, The Impact of Federal Taxes 58 (1943); Polisher, The Family Trust-Its Intcome Tax Fate, 49 Dick. L. Rev. 33, 34 (1945). Congress has so far been unwilling to assume that all trusts set up among members of the same family are in fact controlled by the grantor. Rather, it has left to the courts the task of deciding this issue in each case. Kennedy, Federal Income Taxation of Trusts and Estates 631 (1948) Hereinafter cited as KENNEDY).

5. Helvering v. Clifford, 309 U.S. 331 (1940).

6. The Court stated that "the short duration of the trust, the fact that the wife was the beneficiary, and the retention of control over the corpus by [the settlor] all lead irresistibly to the conclusion that [he] continued to be the owner for purposes of section 22(a)." Id. at 335.

7. "[T]he answer to [whether the grantor may still be treated as taxable owner after the trust is established] must depend upon an analysis of the terms of trust and all the circumstances attendent on its creation and operation. And where the grantor is trustee and the beneficiaries are members of his family group, special scrutiny of the arrangement is necessary lest what is in reality but one economic unit be multiplied into two or more by devices which, though valid under state law, are not conclusive so far as $\$ 22(a)$ is concerned." Ibid. (emphasis added.).

For a detailed study of the immediate effects of the Clifford case see Pavenstadt, The Broadened Scope of Section 22(a): Evolution of the Clifford Doctrine, 51 YALE L.J. 213 (1941).

The Second Circuit pioneered in interpreting and applying the Clifford decision in order to tax holders of economic control strings. See, e.g., Commissioner v. Berolzheimer, 116 F.2d 628, 630 (2d Cir. 1940) (settlor-trustee of a short-term trust for support of children) ; Helvering v. Elias, 122 F.2d 171 (2d Cir. 1941) (wife settlor, husband trustee has sole discretionary control over income during children-beneficiaries' minority); Commissioner v. Buck, 120 F.2d 775 (2d Cir. 1941) (irrevocable trust by settlor husband for wife beneficiary, with administrative powers reserved by the husband settlor). For an exhaustive compilation to mid-1949 of Courts of Appeal decisions based on the Clifford rationale see KENNEDY $\$ 6.29$.

The Treasury's "Clifford Regulations," promulgated in 1945 and amended in 1947, purport to codify and elaborate the criteria of factual control set forth in the Clifford case. U.S. Treas. Reg. 111, $\$ \$ 29.22$ (a) $-21,22$ (1947). But they actually go beyond the case itself in prescribing settlor taxability. The settlor is taxable under the Regulations if corpus or income will revert to him after a short number of years; or if beneficial enjoy- 
However, lower courts, in interpreting the Clifford case, have applied its methods only where the terms of the trust are ambiguous. Limiting their inquiry to the terms of the trust agreement, they have refused to examine actual conduct where the instrument clearly defines the rights of the parties to the trust. If these rights are distinctly delineated, courts have held that the terms of the trust determine conclusively the issue of taxable ownership. ${ }^{8}$ Consequently, taxpayers may avoid the Clifford test by astute wording of their trust agreements.

Funk v. Commissioner ${ }^{9}$ is an example of this way of escaping the Clifford principle. In this recent case, the settlor established four identical trusts. ${ }^{10}$ $\mathrm{He}$ appointed his wife as trustee, authorized her to distribute the income to herself or to him according to their respective "needs," and made her sole

ment is subject to his power of disposition; or if trust corpus or income might be administered for his benefit. Thus the Commissioner treats each of these factors as an independent ground for taxability, whereas the Clifford case relied on all of them as the basis for taxing settlor. For a general discussion of these Regulations, see Eisenstein, The Clifford Regulations and the Heavenly City of Legislative Intention, 2 TAX L. REv. 327 (1947) ; Guterman, The New Clifford Regulations, 1 TAX L. REv. 379 (1946).

The courts have so far been unwilling to accept the Regulations' interpretation. They generally refuse to impose a tax unless more than one of the indicia of control are present. See, e.g., Chertoff v. Commissioner, 160 F.2d 691, 696 (6th Cir. 1947) ("as pointed out in the Clifford opinion, no one fact is normally decisive, but all considerations and circumstances are relevant to the question of ownership and should be considered in making findings on that issue....").

8. E.g., Commissioner v. Katz, 139 F.2d 107 (7th Cir. 1943). The nature of those rights are interpreted and controlled by state law, e.g., Helvering v. Stuart, 317 U.S. 154 (1942); Commissioner v. Child's Estate, 147 F.2d 368 (3d Cir. 1945). Where a state court has adjudicated on the merits the nature of the interests created by a trust agreement, its determination will be accepted as conclusive in federal tax litigation. Blair v. Commissioner, 300 U.S. 5 (1937) ; Freuler v. Helvering, 291 U.S. 35 (1934). See 6 MERTENS $\$ 36.56$.

The Commissioner has frequently turned this argument to his own advantage in order to tax the holders of authorized powers which have never been actually exercised. E.g., Bunting v. Commissioner, 164 F.2d 443 (6th Cir. 1947). This approach is criticized in Flack, Unexercised Rights to Receive Income, 22 TAXEs 211 (1944).

9. 185 F.2d 127 (3d Cir. 1950).

10. Transcript of Record, pp. 171a-172a, Funk v. Commissioner, 14 T.C. 198 (1950).

The circumstances surrounding the creation of these trusts indicate that they were set up for tax avoidance purposes. Four trusts were set up instead of one because the settlor's tax consultant, who was also co-director of his personal holding company, informed him that "there would result some modification in taxes." Ibid. Moreover, these trusts were created at the end of 1936, the year in which Congress established the surtax on the undistributed income of personal holding companies, and the corpus of each trust consisted of $20 \%$ of the dividend-paying stock in settlor's personal holding company. Brief for Commissioner, p. 6, Funk v. Commissioner, 185 F.2d 127 (3d Cir. 1950) (all briefs hereinafter cited refer to this appeal). 
judge of those "needs."11 Undistributed income was to be accumulated for the benefit of contingent beneficiaries. ${ }^{12}$

The Commissioner sought to tax the trust income to the wife. ${ }^{13} \mathrm{He}$ argued that "needs" was an ambiguous standard of income distribution. ${ }^{14}$ Therefore, he claimed, the extent to which this standard actually restricted the wife's personal control should be interpreted in the light of circumstances surrounding the operation of the trust. And he alleged that these circumstances were sufficient to establish her substantial ownership for income tax purposes. ${ }^{15}$

The Tax Court upheld the Commissioner's imposition of the $\operatorname{tax}^{16}$ but employed a different theory. It found the trust language to be clear and unambiguous. ${ }^{17}$ But it held that the "needs" standard was not sufficiently restrictive to limit the wife's control.18 Therefore, since she had, in effect, unlimited discretion, it taxed the income to her as an individual owner.

11. Findings of fact, 14 T.C. 198, 204 (1950).

12. Ibid. The grantor retained the power to appoint by deed or will, but in default of such appointment, the grantor's three children were designated contingent remaindermen. Brief for Taxpayer, p. 3. Thus the grantor, by retaining the power to deprive the children of their contingent rights, made certain that they would not enforce any of the trust standards against his interest.

On the day that the trusts were set up, the spouses also exchanged letters to establish that the wife received full discretionary power over the distribution of trust income. These letters were evidently intended to emphasize the grantor's complete relinquishment of control. Id. at 3-4.

13. Earlier, the Commissioner had attempted to tax the entire trust income to the settlor. But the Board of Tax Appeals upheld the taxpayer. Wilfred J. Funk, P-H 1944 TC MEMr. DEC. 100 (1944). For the most part it relied on the letters exchanged between the spouses and on testimony of the wife that she had exercised unfettered command over the income in practice, as the parties had intended. Id. at 104.

14. "... the terms of the trust were too nebulous to provide any real standard by which a court of equity could have determinted (sic) whether taxpayer abused her discretion with respect to the trust income, no matter how she disposed of the income." Brief for Commissioner, p. 14.

15. Id. at $17-25$.

16. The Tax Court upheld the Commissioner initially in Funk v. Commissioner, 7 T.C. 890 (1946). See Comment, 35 Geo. L.J. 284 (1947). But on appeal, the Court of Appeals remanded, 163 F.2d 796 (3d Cir. 1947), because the lower tribunal had incorrectly taken judicial notice of part of the record in the Wilfred J. Funk case, P-H 1944 TC MEMr. DEC. 100 (1944); see note 13 supra. On remand, the entire Wilfrcd J. Funk record was incorporated by stipulation as $a^{-}$finding of fact. This was the only new factor in the case. The Tax Court again sustained the Commissioner, and elaborated upon its reasoning. 14 T.C. 198 (1950).

17. Id. at 212 .

18. Id. at 213 .

Considerable tax litigation has been concerned with the adequacy of standards such as "needs." While some courts feel such a standard is a sufficient guide for trustee's actions, e.g., Jennings v. Smith, 161 F.2d 74 (2d Cir. 1947), others regard such standards as nebulous and unsatisfactory, e.g., Hurd v. Commissioner, 160 F.2d 610 (1st Cir. 1947). Moreover, adequacy for federal tax purposes seems to depend on the applicable state law. Helvering v. Stuart, 317 U.S. 154 (1942); Johnson v. Helvering, 141 F.2d 208 (2d Cir.), cert. denied, 323 U.S. 715 (1944). See KENNEDY \&1.01 (1948). Dependence 
The Court of Appeals reversed the Tax Court's holding. ${ }^{19}$ It agreed that the trust language was unambiguous. But the Court held that the income was not taxable to the wife under that language, since it found that the terms of the trust established an adequately restrictive fiduciary standard of conduct. ${ }^{20}$ Therefore, the Court reasoned, the wife controlled the income as a circumscribed trustee rather than as an individual owner. ${ }^{21}$

In the light of all the facts in the Funk case, such a conclusion is unrealistic. The trustee-wife's expenditures had been dictated by her whim alone in each taxable year. ${ }^{22}$ Furthermore, the acquiescence in the wife's arbitrary conduct by all other interested parties vitiates the Court's implication that they would in fact enforce their rights under the instrument to curb her abuse of authority. ${ }^{23}$ The Court, however, disregarded these factors. Thus the actual relationship of the parties played no part in the determination of taxable ownership. ${ }^{24}$

on diverse local criteria for interpretation of supposedly uniform federal laws is of dubious merit. Cf. U.S. v. Pelzer, 312 U.S. 399, 402 (1941) ; Lyeth v. Hoey, 305 U.S. 188, 194 (1938). See, e.g., Bartlett, The Impact of State Law on Federal Income Taxation, 25 Chi-Kent L. Rev. 103 (1947).

In the Funk case, both husband and wife had such large independent incomes of their own that the Tax Court found difficulty in envisioning them as "needing" anything more. 14 T.C. 198,213 (1950).

19. 185 F.2d 127 (3d Cir. 1950).

20. Id. at 129-32.

The Circuit Court simply followed another of the possible approaches to the "needs" standard. See note 18 supra.

21. 185 F.2d 127, 131 (3d Cir. 1950).

22. 14 T.C. 208-9 (1950). Taxpayer actually distributed about $97 \%$ of the trusts' net income during the litigated years. About two-thirds of the income was distributed to the husband. "In every instance during the taxable years, she had no particular reason for the decision which she made to distribute part of the trust income to her husband. If she felt like giving him some of the income of the trusts, she did so because she is very fond of him." Id. at 209. She used money which she distributed to herself for a Rolls Royce automobile, a mink coat, a sable coat, and payment of premiums on a policy insuring her husband's life which she took out, with herself as beneficiary. Ibid.

23. The only parties with standing to sue were the husband-recipient of the distributed income, and his minor children. And the husband had retained the power to deprive rebellious children of their contingent interest by naming other beneficiaries in his will. See note 12 supra. Even if a court of equity had been called in to restrain distribution, it is unlikely that it would have done so. Courts traditionally refuse to interfere with a trustee in the absence of clear proof of bad faith or abuse of discretion. E.g., Commonwealth-Merchants Trust Co. v. Seglie, 127 N.J. Eq. 160, 12 A.2d 153 (1940). Since the settlor acquiesced in the trustee's conduct in the Funk case, it would seem impossible for the children to convince an equity court that the trustee had abused the powers which the settlor intended for her. See Cox v. Commissioner, 110 F.2d 934, 936 (10th Cir.), cert. denied, 311 U.S. 667 (1940) ("When consideration is given to the broad powers vested in the donor [as trustee] and to the relationship existing between the donor and the beneficiaries, it is wholly improbable that a beneficiary would exercise his right to resort to a court of equity to restrain the discretion of the donor.").

24. The procedure followed was in line with previous judicial assertions that "the issue involved is one of construction of the trust instruments, a pure question of law." See, e.g., Hallowell v. Commissioner, 160 F.2d 536, 538 (3d Cir. 1947). This rule is 
The Commissioner as well as the courts worked within the framework of the trust instrument's terms. ${ }^{25} \mathrm{He}$ contended for consideration of the actual operation of the trust in this case only because he believed that the trust instrument was "nebulous." 26 If the instrument had clearly established a restrictive standard to direct the trustee, the Commissioner's logic as well would have precluded examination of the actual administration of the trust.

Refusal to look beyond the terms of the trust instrument by courts and Commissioner permits widespread circumvention of the Clifford doctrine. In the Funk case, the Court of Appeals allowed the wife-beneficiary to exercise actual control over the trust income without incurring income tax liability. Under the rationale of this case, the settlor himself may as easily exercise control though insulated from taxes. ${ }^{27}$ As long as the terms of trust clearly give a "substantial adverse interest" to a third party, the court will bar external indicia of settlor domination. ${ }^{28}$

common in federal tax litigation. Paul, Studies in Federac Taxation 280 (3d Series 1940).

On the other hand, some courts have examined the conduct of the parties and their relationships in order to appraise the enforcibility of trust standards in realistic terms. Such opinions make no reference to the necessity for an "ambiguity" in the trust instrument as a basis for their examination and holding of taxability. E.g., Commissioner v. Caspersen, 119 F.2d 94 (3d Cir. 1941), cert. devied, 314 U.S. 643 (1943) (settlor-wife, husband-trustee had discretionary powers of distribution). "The income was in fact distributed in the grantor's interest...." Id. at 97. Cf. Cox v. Commissioner, 110 F.2d 934 (10th Cir.), cert. denied, 311 U.S. 667 (1940).

25. "The Commissioner, likewise, rests upon the contention, that within the framework of the trusts, the income, for all practical purposes, was the taxpayer's own money." Funk v. Commissioner, 185 F.2d 127, 129 (3d Cir. 1950) (emphasis added).

26. Brief for Commissioner, pp. 14, 25.

27. Today it makes little difference whether settlor or beneficiary is held to be the owner of income for tax purposes when they are husband and wife. Spouses now enjoy the benefits of the "income-splitting" joint return provision incorporated into the revenue laws in 1948. INT. REv. CoDE $\$ 51(\mathrm{~b})$. This permits a married couple to divide their combined income in half, to compute the tax on one-half, and to multiply the tax by two. Where the income of one spouse exceeds that of the other by any substantial amount, the total tax paid is less than the amount which would be paid on the separate incomes because of the graduated rates which fall more heavily on the higher brackets. Thus the trust device will not afford a further tax advantage where joint returns are filed unless the trust income can be ascribed to someone other than the spouses. And the Treasury will not care which one of the spouses is taxed because of control over trust income. In the Fink case, the joint return provisions did not apply because pre-1948 taxable years were involved.

28. The "substantial adverse interest" criterion appears in INr. REv. CODE $\$ 167$. This section provides that where any part of trust income is or may be accumulated for future distribution to settlor, or presently distributed to him, or applied to payment of life insurance premiums on his life, either in the settlor's discretion or in the discretion of any person not having a "substantial adverse interest" in the distribution of that part of the income, that part is taxable to the settlor rather than the trust. Congress inserted the words "substantial adverse interest" to replace "beneficiary" in the Revenue Act of 1932, \$167(b), 47 Stat. 221 (1933). The legislative history of this change indicates that Congress wanted to tax trust income to grantor unless control over that income has 
Such limited inquiry may well serve a valid function outside the tax field. ${ }^{29}$ When disputes arise among parties to written instruments, the framers' intent at the time of writing governs their rights. ${ }^{30}$ And the written instrument has been accepted as the only reliable evidence of that intent. ${ }^{31}$ Therefore, in the absence of some ambiguity which necessitates the consideration of external circumstances to determine intent, courts have excluded extrinsic evidence. ${ }^{32}$

But this principle should not govern the Commissioner's determination of the taxability of trust income. The revenue laws are not only concerned with the settlor's intent toward other parties when he drafted the trust instrument. For more than a decade, the Supreme Court has acknowledged

been given to someone whose interests are substantially adverse to his own in fact, rather than merely technically adverse under local trust law. SEN. Rep. No. 665, 72nd Cong. 1st Sess. 34 ; House Rep. No. 708, 72nd Cong., 1st Sess. 25 ; House Conf. Rep. No. 1492, 72nd Cong., 1st Sess. 16 (1932). See Jones, Trusts: Instrumentalities For Avoiding Taxes, 27 Geo. L.J. 18, 21 (1938).

Courts have sought to enforce this legislative purpose by giving narrow scope to interpretations of "substantial adverse interest." "It can be said generally, on the basis of the later decisions, that the grantor's husband or wife will not be considered a person in substantial adverse interest unless both the 'substantial' and 'adverse' nature of his or her interest is clear." 6 Mertens $\$ 37.13$ (1949). But this determination is often made solely from the terms of the trust instrument. See note 24 supra.

29. This exclusion of often relevant evidence is usually imposed by the Parol Evidence Rule. Generally stated, the rule is that the contents of a written document cannot be contradicted or varied by parol evidence, or evidence extrinsic to the writing, provided the writing is valid, complete and unambiguous, and there is no fraud or mistake involved. And the instrument is held to be not ambiguous when its words have a well-settled legal meaning. See, e.g., Central Hanover B. \& T. Co. v. Herbert, 1 N.J. 426, 429, 64 A.2d 75, 76 (1949); 9 Wigmore, Evidence $\$ 2425$ (3d Ed. 1940).

30. Speth v. Speth, 8 N.J. Super. 587, 74 A.2d 344 (1950). "The policy of the law is to construe a . . . trust so as to make it conform to the intent of the . . . donor." Oak Investment Corp. v. Martin, 107 N.J. Eq. 123, 126, 151 A.2d 874, 876 (1930). Cf. Shelton v. King, 229 U.S. 90, 101 (1913).

31. E.g., Zone Co. v. Service Transportation Co., 137 N.J.L. 112, 57 A.2d 562 (1948); Van Syckel v. Dalrymple, 32 N.J. Eq. 233 (1880). See 9 Wignore, Evidence $\$ \$ 2425$, 2459 (3d Ed. 1940); Holmes, The Theory of Legal Interpretation, 12 HARv. L. Rev. 417,420 (1899).

Even where courts admit evidence of the circumstances under which the writing was made, the general rule is that "such evidence is received, not for the purpose of importing into the writing an intention not expressed therein, but simply with the view of elucidating the meaning of the words employed. ..." 32 C.J.S. 913 (1942).

32. E.g., Zone Co. v. Service Transportation Co., 137 N.J.L. 112, 57 A.2d 562 (1948). Admitting extrinsic evidence to vary the written instrument is said to open the way to fraud and commercial uncertainty. Ibid.; Cargill Commission Co. v. Swartwood, 159 Minn. 1, 198 N.W. 536 (1924). But see Zell v. American Seating Co., 138 F.2d 641 (2d Cir. 1943) (attack by Judge Frank on the idea that parties to written instruments place any real reliance on the Parol Evidence Rule's ability to protect them from fraud). "[I]t is unlikely that commercial disaster would follow even if legislatures abolished the rule in its entirety." Id. at 649 .

For discussion and criticism of the rule, see generally Corbin, The Parol Evidence Rule, 53 YaLE L.J. 603 (1944). 
factors of economic control as a basis for taxability. ${ }^{33}$ The written expression of settlor's intent is not necessarily the most revealing criterion of such control. ${ }^{34}$ Moreover, disregard of parties' conduct permits use of trust agreements as instruments of collusion. Since all participants share a common interest in defeating the Commissioner's tax claims, the language of the instrument may have been purposely selected in order to achieve tax avoidance. $^{35}$ The Clifford policy cannot be effectuated unless courts consider all circumstances bearing on the operation of trusts.

33. See, e.g., Helvering v. Horst, 311 U.S. 112 (1940); Helvering v. Clifford, 309 U.S. 331 (1940) ; Burnet v. Wells, 289 U.S. 670 (1933) ; Corliss v. Bowers, 281 U.S. 376 (1930); Lucas v. Earl, 281 U.S. 111 (1930).

Control may be manifested either by power or its exercise. Basing taxability solely on the terms of trust may have originated in the Commissioner's frequent attempts to tax the power alone, though unexercised. See note 8 supra. But the fact that power to exercise control is taxable in itself as sufficient "ownership" should not preclude taxation when unopposed actual exercise of unauthorized power is shown. Not only authorized power, but exercised power as well should amount to ownership within the meaning of the tax laws. Cf. Helvering v. Horst, 311 U.S. 112, 118 (1940) ("The power to dispose of income is the equivalent of ownership of it. The exercise of that power to procure the payment of income to another is the enjoyment, and hence the realization, of the income by him who exercises it.") (emphasis added.) Courts, however, have not been willing to go so far. When someone exercises unauthorized powers, he is not held taxable. E.g., Commissioner v. Lewis, 141 F.2d 221 (3d Cir. 1944).

34. Helvering v. Clifford, 309 U.S. 331 (1940); see Paul, Studies IN Federal Taxation 277 (3d Series 1940). See Commissioner v. Culbertson, 337 U.S. 733, 740 (1949) ("The vagaries of human experience preclude reliance upon even good faith intent as to future conduct as a basis for the present taxation of income.").

35. Even by traditional Parol Evidence Rule standards, see note 29 supra, the Commissioner need not be bound by the terms of the trust agreement. "It is commonly said that the Parol Evidence Rule . . . is binding upon only those persons who are partics to the document." 9 WIGMORE, EvIDENCE $\$ 2446$ (3d Ed. 1940). Third parties may usually escape the application of the rule by showing that the instrument is not a complete integration of the rights and obligations arising between the original parties and themselves. Ibid. On the other hand, it is generally agreed that "where the issue in dispute, even between third parties, is what are the obligations of A and B to one another, and those obligations are stated in a written contract, the parol evidence rule is applicable." 3 Wtuliston, Contracts $\$ 647$ (Rev. Ed. 1936); see Wigmore, supra. Compare Stern v. Commissioner, 137 F.2d 43, 46 (2d Cir. 1943) with Pugh v. Commissioner, 49 F.2d 76, 79 (5th Cir.), cert. denied, 284 U.S. 642 (1931). 